\title{
Die skeppingsordeninge en homoseksualiteit
}

\author{
RM Naudé
}

\section{Abstract}

The ordination of creation and homosexuality

The idea of creation ordinances is treated according to the theologies of Emil Brunner, Karl Barth and Helmut Thielicke in the light of the conjugation of the ordinance and homosexuality by Heinrich Ott on the one hand, and between the ordinance and the relation between dogmatics and ethics by Walter Kreck on the other hand. This results in the theory that the evaluation of homosexuality depends on the balanced relation between dogmatics and ethics to avoid ortodoxism and moralism.

\section{INLEIDEND}

Die leer van die skeppingsordeninge omskryf die bestaan van die mens binne bepaalde ordeninge soos volk, staat, ras, huwelik, familie en gemeenskap. As ordeninge van God die Skepper word hiermee onveranderlike eise bedoel wat onvoorwaardelik geldig is (Lau: 1961). Die leer van die skeppingsordeninge het in die hede aktueel geword veral deur middel van die bydrae van twee teoloë. Heinrich Ott (1981: 182-189) het oor die skeppingsordeninge besin soos dit uitgedruk word binne die gesigspunt van die natuurreg, die openbaring in Jesus Christus en God as Skepper. Hierdie besinning het hy veral betrek op die huwelik en homoseksualiteit. Hy vra die vraag of ' $n$ ander vorm van die huwelik moontlik is in die sin van 'n kommune huwelik? Kan homoseksualiteit as teennatuurlik of as natuurlik beskryf word? Die leer van die skeppingsordeninge word aktueel gemaak omdat dit verbind word aan homoseksualiteit as 'n eietydse vraagstuk. Walter Kreck (1975: 114) het aan die hand van die leer van die skeppingsordeninge die probleem van die verhouding tussen dogmatiek en etiek behandel. Die vraag wat hiermee gestel word is of die skeppingsordeninge eensydig beskou mag word as 'n etiese imperatief sonder om die dogmatiese vraagstelling in ag te neem? Hiermee word die immer 
aktuele probleem van die verhouding tussen dogmatiek en etiek aan die orde gestel. Die twee aspekte van die skeppingsordeninge wat hiermee na vore gekom het, is nie losstaande van mekaar nie. Die verhouding tussen dogmatiek en etiek het te doen met die eise wat die skeppingsorde kan stel aan homoseksualiteit. Nog sterker gestel: Die verhouding tussen dogmatiek en etiek bepaal die beoordeling van homoseksualiteit. Om dié aangeleentheid aan die orde te stel, word die teologie van Emil Brunner, Karl Barth en Helmut Thielicke ondersoek. Hierdie drie teoloë word spesifiek gekies vanweë die kontrovers tussen Brunner en Barth oor die skeppingsordeninge en natuurlike teologie, en vanweë die feit dat Thielicke gereken word as 'n eksponent van die nuwere denke oor homoseksualiteit.

\section{EMIL BRUNNER}

Brunner (1950: 30) beskou die skeppingsordeninge in noue samehang met die skeppingsopenbaring. Met hierdie vertrekpunt word Brunner se aanhang van die dialektiese teologie duidelik. Sy vertrekpunt impliseer dat God alleen déúr sy handeling geken kan word deur middel van die geloof, wat gegrond is in die openbaring van God in Jesus Christus. Die goeie handeling van die mens kan daarom alleen as goed beskou word in soverre God self daarin handel deur die Heilige Gees. Daarom beskou Brunner etiek as deel van die dogmatiek en verbind hy die menslike daad met God se daad. Hy definieer die Christelike etiek as die wetenskap van die menslike handeling soos dit deur die handeling van God bepaal word (1939: 71, 72).

Brunner (1934: 18) se besinning oor die menslike handeling begin by die gebod van God as Skepper. Dit vertoon ooreenkomste met die teologie van Karl Barth. Hy verstaan die wil van God op 'n tweevoudige wyse. Die wil van God is kenbaar in sy handeling as Skepper en as Verlosser. Die versoening plaas hy in die middelpunt van die tyd wat hy indeel in verlede, hede en toekoms. God kyk na die verlede as Skepper en na die hede as Verlosser. Met hierdie tweevoudige beskouing wil Brunner (1939: 106-108) aandui dat die skepping en die verlossing alleen verstaan kan word vanuit die versoening. Vanweë die sonde ken die mens God nie vanuit sy skepping nie. Die boek van die skepping slaag nie daarin om die sondige mens die Skepper reg te laat ken nie. Eers deur middel van die geskrewe boek naamlik die Bybel kan die mens in die beeld van God, Jesus Christus, die Skepper leer ken 
soos Hy werklik is (1934: 19). Die eintlike van die Skepper word aangedui as die Heer-wees van God. God as Skepperheer het 'n onvoorwaardelike aanspraak op die mens omdat alles wat die mens is en wat rondom die mens is van Hom kom. Dat God Skepper is beteken dat die Skepper wêreldheerser is aan wie die mens behoort. Eintlik word die mens eers werklik mens as die mens 'kneg van God' geword het. Daarom beteken die geloof in God die Skepper om Hom as heer te gehoorsaam (1934:20, 21). Die feit dat die skepping deur die sonde verwring is beteken dat die Skepperwil van God slegs op indirekte wyse geken kan word. Hy wil nie die skepping wat versteur is nie, maar hy wil die eintlik skepping (1939: 110). Daarom kan die mens die wêreld nie aanvaar soos dit is nie. Brunner sien die gebod van die Verlosser as 'n 'nee' tot die wêreld soos dit is. Om die wil van God gelyk te stel met die skepping soos dit is, is om van die wil van God 'n karikatuur te maak. Die gebod en die ordening van God moet daarom gesoek word (1939: 112). Brunner (1939: 112-115) beskryf die gebod van die Skepper en die gebod van die Verlosser as konserwatief en revolusionêr. Dit beteken dat die mens hom sal onderwerp aan die konkrete aktualiteit van sy bestaan. God as Skepper maak dit aan die mens bekend in watter sfeer om te leef en te handel. Sò gee $\mathrm{Hy}$ aan die menslike aktiwiteit ' $n$ basis van soliede realiteit. God as Verlosser gee die motivering en rigting aan die realiteit van die menslike lewe wat gevul word met liefde. As Skepper onderhou God die wêreld met 'n geduldige 'Ja'. As Verlosser gryp Hy in, en herskep Hy. Dié goddelike liefde offer homself in die wêreld deur Jesus Christus om daardeur die mens uit te skeur uit sy sondige bestaan (1939: 112-115).

Op grond van die onderskeid konserwatief en revolusionêr wil Brunner (1939: 375) nie net 'n apodiktiese leer na vore bring sonder om te besin oor die menslike realiteit nie. Hy wil leerstellinge ontwikkel in die lig van die realiteit van die hede. Die gebod van God wat gehoorsaamheid vra wil hy nie laat swewe bo die bestaan van die mens nie, maar hy wil dit die hart van die bestaan van die mens laat ontmoet. Vir hierdie doel is die skeppingsordeninge van belang. Die wêreld is volgens Brunner klaar georden. Die gegewene is die wil van God.

Die gegewe orde dra die karakter van ' $n$ indikatief en 'n imperatief. Die imperatief van die gegewe orde is: Die mens moet hom laat begrens deur hierdie ordening en antwoord gee op die eis wat gestel word. Die mens moet hom in die ordening inorden (1939: 108, 109). Brunner skep hiermee die indruk dat hy die skeppingsordeninge sien as 'n starre konstantheid in 'n mens se lewe. Hy erken tog die historiese verander- 
baarheid van die ordeninge omdat hy die skeppingsordeninge sien as gemeenskapsordeninge. Die skeppingsordeninge is vir hom die voorwaarde vir die lewe wat in sy grondstruktuur onveranderlik is (1939: 194). As gemeenskapsordening het dit wel wisselende vorme omdat dit 'n werking van die sonde is (1939: 321). Hierdie wisseling in vorm kan egter nie gesien word as 'n dialektiek tussen gebod en situasie of selfs as 'n onderbou vir die situasie etiek nie (Henry 1973: 74). Die redes hiervoor lê in die uitgangspunt dat God die Skepperheer is wat gehoorsaam moet word sowel as die beskouing dat die skeppingsordeninge ' $n$ protes is teen die vorm van die ordeninge wat vanweë die sonde verander. Só gesien is die skeppingsordeninge 'n diens aan die gemeenskap (1939: 320) omdat die vasgelegde orde wat gestel word die gemeenskap beskerm teen chaos (1950: 30). Dié onveranderlike orde word deur Brunner beskryf as die sosein van die kreatuur wat as die wil van God ook 'n natuurwet is. Hiermee stel hy die natuurwet gelyk aan die skeppingsordeninge. Op grond hiervan ontwikkel Brunner (1950: 31) 'n Christelike theologia naturalis. Hierdie aspek van die teologie van Brunner word as ' $n$ breuk met die dialektiese teologie beskou (Berkouwer 1974: 41). Dié breuk word akuut in sy teologie van die aanknopingspunt (Steck 1962: 89). Brunner (1934: 54) beskryf die skeppingsordeninge as ingeplant in die natuur van elke mens deur die Skepper sodat elke mens instinktief die ordeninge kan ken. Daarom beskryf Brunner (1939: 329) die skeppingsordeninge as 'n orde wat gegee is gepaard met dit wat geskep is. Dit is 'n orde wat nie geëlimineer is deur die sonde nie, maar waarvan die natuurlike mens bewus kan wees. Hierdie natuurlikheid van die skeppingsordeninge is die wysheid van God om mense wat van mekaar verwyderd en gemeenskaploos geword het tot gemeenskap te dwing en daardeur menslike lewe moontlik te maak (Brunner 1939: 194). Só is die skeppingsordening in sy natuurlikheid 'n middel tot opleiding van die gemeenskap om die mens nolens volens in gemeenskap met ander te plaas en eise te stel (Brunner 1939: 320). Brunner spits dié denke veral toe op die huwelik. Hy fundeer monogamie nie aan die hand van die dialektiese teologie nie, maar wel aan die hand van die theologia naturalis. Hy sien die menslike bestaan as gebonde aan twee ander mense naamlik ' $n$ kind is verbonde aan sy twee ouers. Hierdie mense is verbind aan mekaar deurdat die ouers aan die kind sy menslike bestaan gee. Die kind is nie ' $n$ blote objek waarvan ouers hulle onaangeraak kan losmaak nie, maar is self as mens 'n subjek wat 'n onderlinge relasie skep wat die gesin bymekaar hou. Dit noem Brunner (1939: 330) die menslike bestaanstruktuur. Hierdie bestaan- 
struktuur word tipeer deur die natuurlike liefde wat in sy essensie monisties van aard is. Dit fundeer hy in die feit dat die tussenkoms van 'n derde person as 'n steurnis in die huwelik beleef word (Brunner 1939: 331). Die bestaanstruktuur van die mens gevul met liefde beskryf Brunner as 'n skepping van God. Hy het juis die aard van die liefde geskep ter wille van die uniekheid van die bestaanstruktuur (Brunner 1939: 332). Die monistiese aard van die bestaanstruktuur beteken dat' $n$ mens slegs 'n man word deur middel van sy vrou en vrou slegs 'n vrou word deur middel van haar man (Brunner 1939: 334). Alhoewel Brunner nie 'n direkte uitspraak maak oor homoseksualiteit nie kan aanvaar word dat die struktuur van sy teologie nie ruimte laat vir homoseksualiteit nie. Sy beskrywing van liefde openbaar wel geduld en aanvaarding van die mens soos hy is. Hy stel egter dat ware liefde ook beteken om 'n persoon te lei na sy skeppingsdoel wat hyself nog nie gesien het nie (Brunner 1939: 114). In die lig van die versoening kan die skeppingsdoel nie anders gesien word as om revolusionêr besig te wees met dit wat die mens is nie. Die klem word nie gelê op wat die mens is nie maar wat die mens moet word volgens die skeppingsordeninge.

\section{KARL BARTH}

Barth het die teologie van die aanknopingspunt van Brunner heftig aangeval. Hy was veral verontrus oor die leer van die goddelike vonk wat in die mens oorgebly het na die sondeval. Dit het Barth verstaan as 'n aanduiding dat die goddelike vonk slegs aangeblaas hoef te word deur natuurlike dinge soos die gemeenskap of deur opvoeding om 'n vlam van essensiële goedheid te skep (Henry 1973: 73). Daarom beveg Barth die leer van die skeppingsordeninge as synsordeninge. Hy het dit afgewys as dwaalleer en die analogia entis as 'n uitvindsel van die antichris (Barth 1964: VIII). Dié afwysing het 'n eristiek tot gevolg gehad tussen Barth en Brunner wat tematies saamgevat kan word met die term: analogia entis (Weber 1967: 92). Barth beskuldig Brunner van kasuïstiek alhoewel hy tog instem met die gedagte van Brunner dat die gebod van God nie ' $n$ wet is wat oor die gegewe werklikheid sweef sonder om in verbintenis daarmee te wees nie maar dat dit wel die gebod van God is wat hierdie werklikheid geskep het. Barth vra die vraag: As dit so is dat deur die skeppingsordeninge die gebod van God na ons toe kom dan is dit 'n vraag hoe ons hierdie stem kan hoor en verstaan as 'n riglyn waarvolgens ons moet handel? Alhoewel Brunner 
nie sover gaan soos Althaus om die werklikheid as prinsiep vir sy etiek te sien nie, vra Barth $(1969: 20,21)$ tog die vraag of die lex naturae nie die antwoord is wat Brunner gee op hierdie vraag nie?

Barth se aanval op Brunner kan gesien word teen die agtergrond van sy kritiek op die Ortodoksie van die 16de en 17de eeu. Alhoewel die Ortodoksie van Christus praat, is dit Barth se mening dat hulle eerder steun op Aristoteles of Descartes wat betref die Godsleer, predestinasieleer, die natuurlike teologie en die leer van die skepping en voorsienigheid. Barth noem dit ' $n$ dubbele boekhouding wat die natuur en genade, skepping en verbond, skeppingsopenbaring en heilsopenbaring van mekaar losmaak. Sy kritiek is veral toegespits op die neiging om die boek van die genade te laat verval ten gunste van die boek van die natuur as albei standpunte gehandhaaf word. Die boek wat dan uitsluitlik gelees word is die boek van die natuur (Barth 1970: 476). Barth wys daarom die moontlikheid van 'n aanknopingspunt by die mens af as 'n noodsaaklike voorwaarde vir die kennis van God en die geloof in God. Dié afwysing hang saam met sy teologiese model. Barth stel dat hy nie vanuit die moontlikheid na die werklikheid dink nie, maar wel vanuit die werklikheid na die moontlikheid. Alleen vanuit die werklikheid van die openbaring kan oor die moontlikheid besin word (Barth 1960: 225).

Barth beskrywe die werklikheid met 'n begrip wat hy stel teenoor die analogia entis naamlik die analogia fidei. Die analogia entis druk 'n synsverhouding uit tussen Skepper en geskapenheid, genade en natuur, wat staties, kontinuerend is asof die Skepper en geskapenheid een syn het (Weber 1967: 92). Die analogia fidei druk die teenoorgestelde uit. Dit is nie die handeling van die mens wat beklemtoon word nie, maar wel dié handeling van God. Die feit dat die mens die moontlikheid het om die Woord van God te hoor, berus nie by ' $n$ bepaalde gesteldheid van die mens of aanknopingspunt by die mens nie. Dit is God wat deur Sy Woord handel. Die moontlikheid om die Woord van God te erken lê in die Woord van God self. Die moontlikheid word gebore vanuit die werklikheid van God (Barth 1964: 255-257). Daarom het die mens nie sy eie geloof geskep nie maar die Woord skep dit. Die mens kom nie tot geloof nie, maar die geloof kom deur die Woord tot die mens. Die mens skep nie geloof nie, maar dit word geskenk deur die Woord (Barth 1964: 258). Die analogia fidei wil op hierdie wyse uitdruk dat die mens die objek van die geloof is. Die lewe van die mens word daarom deur die Woord bepaal (1964a: 258).

Die mens is egter nie alleen 'n objek van die geloof nie maar ook 'n 
subjek van die geloof. Barth (1964a: 258) noem dit die analogia relationes. Hierdie analogie is ten diepste gegrond in die ooreenstemming (Entsprechung) en die ooreenkoms (Ähnlichkeit) tussen die verhouding in die pluraliteit van die syn van God en die verhouding tussen die syn van God en die mens. Dié verhouding bestaan daarin dat dieselfde ewige liefde waarmee God die Vader die Seun liefhet en die Seun die Vader liefhet ook die liefde is waarmee God die mens liefhet (Barth 1959: 262). Dié relasie kom dan veral tot uitdrukking in die skepping van die mens as man of vrou. Soos die aanroepende $\mathrm{Ek}$ in die wese van God in verhouding staan met die aangeroepe $U$, so staan God in verhouding met die mens wat self in 'n verhouding van ek tot jy, man tot vrou staan. Met hierdie vergelyking word nie 'n synsgelykheid uitgedruk nie maar wel ' $n$ analogie, 'n ooreenstemming tussen ongelykes (Barth 1970: 220). Hiermee word die relasie tussen mense bepaal deur die relasie tussen God en mens sowel as die relasie met Homself. Teenoor die analogia entis stel Barth dus dat geen ander syn as die syn van God die normering is vir die menslike handeling nie.

Die konsekwensie van hierdie denke van Barth is dat vanuit die analogia relationes ' $n$ leer van die appropriationes na vore kom. Hiervolgens is die gebod van God die Skepper, Versoener en Verlosser die normering van die handeling van die mens as uitdrukking van die syn van God (Barth 1969: 36). Hiermee word die verhouding tussen dogmatiek en etiek by Barth aangedui. Barth beskou etiek as teologiese etiek. Dit beteken dat die etiek groei vanuit die dogmatiek. Só loop die leer van die skepping uit op 'n etiek van die skepping. Vir hierdie doeleindes steun die etiek egter nie alleen op die gebod van die Skepper nie omdat kennis van die Skepper nie voldoende kennis van God is nie. Daarom stel Barth (1964b: 35; 1969: 36) dat die eerste artikel van die credo noodwendig gevolg moet word deur die tweede en derde artikel. Dit bring mee dat dié God wat die mens as Skepper ontmoet in sy gebod dié God is wat die mens in Jesus Christus genadig is (Barth 1969: 38). Hiermee verwerp Barth die dualisme: gebod en ordening wat naasmekaar gehandhaaf word (teen Brunner). Die genade van God in Jesus Christus sluit die skepping en die gebod van die Skepper in (Barth 1969: 42). Die Skepper wie se gebod die mens ontvang, is as Skepper in die volle sin van die woord die vriend en weldader van die mens (Barth 1969: 44). Barth stel dit ook anders deur te sê dat die skepping produk van die verbond is en dat die mens verbondsmens is (Barth 1970: 44). In die lig hiervan praat Barth tog van skeppingsordeninge. Hy kwalifiseer dit egter baie duidelik. Dit gaan nie vir Barth om 
'n ordening wat iewers afgelees word of ontdek moet word nie, maar hy verstaan daaronder die ordening as 'n besondere sfeer van goddelike gebooie en menslike handeling wat onder die bevel staan van God die Skepper. Hy wil die skeppingsordeninge nie anders sien as deel van die totale handeling van God met die mens nie. Dit stel Barth teenoor die skeppingsordeninge as 'n Eigengesetzlichkeit. Dit gaan vir Barth nie om 'n ordening wat synsmatige eise aan die mens stel nie. Omdat God die mens as verbondsmens in Jesus Christus sien onderhou Hy die mens as geskapene en bied Hy beskutting aan die mens (Kreck 1975: 120). Ons kan eintlik stel dat Barth die mens só opnuut konfronteer met God as Skepper dat hy die mens nie stel voor 'n skeppingsordening nie maar die mens sien in die lig van die Skeppersordening.

Vanuit hierdie teologiese struktuur besin Barth oor homoseksualiteit. Barth (1969: 168) stel die tese dat dit die gebod van God vir die man en vrou is om volledig man en vrou te wees omdat man en vrou op hierdie wyse imago Dei is. Volledig man en vrou wees behels dat die man en vrou hulle bymekaar voeg (Zuordnung), bymekaar hoort (Zugehorigkeit) en mekaar ondersteun (Zuwendung). In gehoorsaamheid aan die gebod van God is daar vir die man en vrou dus nie 'n afgeslote selfgenoegsame manslewe en vrouelewe nie. Wie man of vrou sê, sê inderdaad man en vrou (Barth 1969: 181). Barth (1969: 182) stel dit nog sterker: Die gerigtheid op mekaar is deel van die wese van die man en vrou. In verhouding tot die vrou word die man ' $n$ man en in verhouding tot die man word die vrou 'n vrou. In die Heer word hulle een en dit verbind hulle saam sodat hulle menslikheid konkreet bestaan in die medemenslikheid van man en vrou (Barth 1969: 183). Vanuit hierdie denke word homoseksualiteit beskrywe as 'n fisiese, psigiese en sosiale siekte. Dit is 'n gestalte van perversie, dekadensie, verval wat intree waar die mens die gebod van God nie meer laat geld nie. Hierteenoor stel die gebod van God die Skepper dat die man saam met die vrou en die vrou saam met die man ware mens is. Binne hierdie ruimte is daar geen plek vir homoseksualiteit nie (1969: 185) en word dit bestempel as onmenslik (Barth 1969: 184).

\section{HELMUT THIELICKE}

Thielicke omskryf die gerigtheid van die gebod van God die Skepper as 'n gemeenskap tussen die skepsel en die Skepper wat gekarakteriseer word deur die imago Dei. Die praktiese betekenis van hierdie gebod is 
dat dit 'n persoonlike ek-U verhouding tot die Skepper daarstel en nie 'n onpersoonlike ek-dit verhouding tot die skepping nie. Thielicke (1981: 250; 251) stel dit in navolging van die woord van Martin Luther: Ek glo dat God my geskep het (1981: 250, 251). Thiehicke grond dit in die leer van die creatio ex nihilo. Dié leerstuk wil betuig dat God alomvattend is. Dit beteken dat die wêreld nie 'n eiemagtigheid besit nie. Die doksologie kom God toe. Die wêreld is begrens. Dit het ' $n$ begin en daarom is 'n regressus ad infinitum onmoontlik (Thielicke 1981: 253, 254). Die implikasie hiervan is dat die Skepper en die skepping nie saamsmelt nie maar dat God 'n soewereine subjek bly teenoor die skepping as objek. God is nie deel van die skeppingsorde nie maar Hy is Skepper van hierdie orde (Thielicke 1981: 263). Die mens het daarom geen moontlikheid om ' $n$ ander gemeenskap met God te hê as die een wat God gee nie. Die leer van die creatio ex nihilo omskryf hierdie gemeenskap as sola gratia. Thielicke sien dit as die nuwe werk van God in die mens sodat die menslike daad nie cooperatio is nie maar eerder 'n bevestiging is van die mens as nuwe skepsel in Jesus Christus. Daarom beskou hy die geskapenheid nie as 'n gegewenheid nie maar as 'n opdrag, 'n verantwoordelikheid wat geloof en gehoorsaamheid vra. Daarom beklemtoon Thielicke (1981: 266) die geskapenheid as Reichsunmittelbar, dit is, die persoonlike verhouding tussen Skepper en skepsel. Dit bring mee dat Thielicke die imago Dei sien as 'n gawe sowel as ' $n$ opgawe. Dit dui nie alleen op die herkoms nie maar ook op die toekoms. Dit is nie alleen iustitia originalis nie maar ook iustitia finalis. Daarom interpreteer hy die imago Dei nie as 'n synsbegrip nie maar as relasiebegrip wat nie die verlede herstel nie maar die verlede oortref omdat dit dui op 'n toekoms in Jesus Christus (Thielicke 1981: 267, 268). Die imago Dei as relasie beteken dat daar by die mens geen aanknopingspunt is nie. $\mathrm{Al}$ is die imago Dei as relasie deur die sonde aangetas bly selfs 'n gebroke relasie nog steeds 'n relasie (Thielicke 1981: 277). Die imago Dei kan daarom nie verlore gaan nie. Dit het 'n character indelebilis in 'n negatiewe sin: Die mens kan nie los word van sy mensheid nie. Elke mens kan op sy mensheid aangespreek word en só bly elke mens verantwoordelik voor God (Thielicke 1981: 289).

Soos by Brunner en Barth bied Thielicke ' $n$ teologiese struktuur waardeur die persoonlike verhouding tussen Skepper en skepsel beklemtoon word en die mens gekonfronteer word met die Skepper as Vader van Jesus Christus. Die vraag is hoe hierdie teologiese struktuur die beskouing van die skepping as leefwêreld van die mens beïnvloed? Thielicke (1981: 249) stel dat dit wat die mens moet, hang saam met dit 
wat die mens is en dit kan alleen bepaal word as vasgestel word vanwaar die mens kom. Daarom is dit van belang dat hy die wêreld in 'n negatiewe lig sien. Hy beskryf die wêreld nie as 'n skeppingsmatige orde nie, maar as 'n bedeling tussen die sondeval en die gerig. Die karakter van hierdie bedeling word bepaal deur die sonde en daarom is die wêreld in al sy lewensuitinge en strukture 'n mundus post lapsum (Thielicke 1968: 699). Só gesien is dit nie vreemd dat Thielicke die mens en wêreld as onlosmaaklik aan mekaar beskou nie. Hy beskryf die wêreldlikheid as 'n eienskap van die mens en die wêreld en sy ordeninge as menslik (Thielicke 1968: 700). Daarom beskou Thielicke die ordeninge van die wêreld nie as skeppingsordeninge nie, maar as ordeninge van die geduld van God of ook genoem noodordeninge. 'n Kenmerk van hierdie bedeling met sy noodordeninge is die noagitiese verbond. Dit beteken dat die sonde van hierdie bedeling gebruik word om die sonde te bekamp. Só word geweld gebruik deur die owerheid om geweld te bekamp (Thielicke 1968: 707). Só spreek Thielicke (1968: 715) ' $n$ veto uit oor die ordeninge van die gemeenskap wat hy as onregsvorme beskrywe. Daarom sien hy die dekaloog nie as uitsprake oor die natuur-reg nie maar as uitsprake oor die natuur-onreg (Thielicke 1968: 712).

Ten spyte van die beskrywing van die ordeninge as noodordeninge beskou Thielicke die huwelik as 'n skeppingsordening omdat dit 'n ordening voor die sondeval is. Daarom funksioneer dit as ' $n$ korrektief vir die sondige handeling van die mens (1968: 596). Dit geld vir alle mense onafhanklik van hulle geloof, as 'n onderhoudingsordening wat die biologiese voorwaarde vir die lewe vorm (1968: 627). Die huwelik as skeppingsordening omvat die bestaan van die mens in sy medemenslikheid. Thielicke stem saam met Barth dat die mens nie 'n keuse het om medemenslik te wees of dit nie te wees nie. Die mens bestaan in hierdie tweeheid (Thielicke 1968: 508). Hy verskil van Brunner se siening dat God tweërlei mense geskep het naamlik 'n manlike en 'n vroulike. Man en vrou word nie bymekaar gevoeg nie maar hulle is as een mens polêr van aard (Thielicke 1968: 509). Die mens kan daarom nie anders bestaan as man en vrou wat op mekaar gerig is nie.

Die struktuur van die teologie van Thielicke kan beskryf word as 'n hamartiologiese denkmodel (Ringeling 1987: 10) wat dogmatiek en etiek aan mekaar verbind. Vanweë die sterk hamartiologiese inslag van sy teologie wil Thielicke elke imperatief en elke vorm van gehoorsaamheid verbind aan een formule: Ek moet God bo alles vrees, liefhê en vertrou. Die tweede tafel van die wet kom na die eerste tafel (Thielicke 
1981: 33). Thielicke sien egter nie etiek as 'n dogmatiese gegewenheid nie, maar ook as ' $n$ analise van die werklikheid. Hy beskrywe etiek daarom nie as 'n praktiese konsekwensie van die dogmatiek nie, maar as aanvullend by die dogmatiek. As analise van die bestaan van die mens wat leef onder die ordeninge van hierdie wêreld, wil etiek die mens konfronteer met die geloofswaarheid (Thielicke 1981: 63, 64).

Dié beskouing van Thielicke bring mee dat hy die fenomeen homoseksualiteit nugter wil beoordeel. Sy beoordeling kan beskryf word as meelydend en pastoraal van aard. Hy steun Barth in die verwerping van die idealisering en sakralisering van homoseksualiteit. Hy beskuldig Barth egter van fenomeenblindheid met die gevolg dat sy etiese aanwysings in 'n lugleegte plaasvind. Die vraag wat Thielicke (1968: 791) na vore bring is hoe die homoseksueel die teologiese aspek self moet verstaan? Hoe moet die homoseksueel handel na aanleiding van die teologiese uitspraak? Kan hy sy homoseksualiteit uitleef of moet hy dit onderdruk. Hoe kan hy sy homoseksualiteit bemeester? Hiermee trag Thielicke om die koue wettiese afwysing van homoseksualiteit te hersien. Die natuurlike instink teen homoseksualiteit moet onder beheer gebring word sodat ongegronde uitsprake nie gemaak word nie. 'n Voorbeeld wat Thielicke noem (1968: 795), is die uitspraak in die 17 de eeu van die Lutherse kerkregleraar Carpzow wat stel dat aardbewings, hongersnood, pes, oorstromings en groot vraatsugtige woelmuise die gevolge is van homoseksualiteit!

Thielicke aanvaar dat binne die Bybelse en gevolglik binne die Christelike denke dit onmoontlik is om homoseksualiteit neutraal te beskryf as ' $n$ gril of as ' $n$ spel. Volgens skeppingsmatige bepaaldheid van die mens kan homoseksualiteit nie anders as perversie beskryf word nie. Homoseksualiteit is nie ooreenkomstig die skeppingsordening nie (Thielicke 1968: 801).

Vanuit hierdie algemene verwerping van homoseksualiteit beredeneer Thielicke (1968: 802-803) ook induktief die situasie van die homoseksueel en stel hy die volgende benadering:

- Homoseksualiteit kan nie gelykgestel word aan die skeppingsmatige geslagtelikheid nie. Daarom word die homoseksueel versoek om sy aard nie positief te aanvaar of te idealiseer nie.

- Die homoseksueel moet bereid wees om binne die raamwerk van moontlike herstel deur behandeling homself in orde te bring.

- Die homoseksueel wat homoseksualiteit aanvaar het as 'n alternatiewe lewenstyl skep 'n teologiese en 'n etiese probleem. Die vraag is 
of die homoseksueel sy habitus seksueel mag verwerklik of mag askese geëis word? Thielicke verwerp askese as eis omdat dit slegs as 'n vrywillige daad regverdig kan word. Hy vra die vraag of op grond van die noagitiese verbond nie soortgelyke norme moet geld vir die onveranderlike situasie van die kern-homoseksueel as vir die normale heteroseksuele verhouding nie?

\section{OPMERKINGS}

Die beoordeling van die fenomeen homoseksualiteit hang ten nouste saam met die verhouding dogmatiek en etiek. Wanneer etiek bloot as 'n uitvloeisel van die dogmatiek beskou word is die gevaar groot dat die resultaat van die beoordeling 'n starre wettiese afwysing tot gevolg sal hê wat blind is vir die situasie of die feitlikheid van die fenomeen. Thielicke word daarom gesteun in sy kritiek teen Barth. Die omgekeerde siening van dogmatiek en etiek lewer net so 'n groot probleem. Wanneer etiek losgemaak word van dogmatiek is relativisme die gevaar. ' $n$ Voorbeeld hiervan is te vind in die beredenering van homoseksualiteit deur die deputate Kerk en teologie van die Gereformeerde Kerke Nederland (GKN). Die beredenering van die deputate (1981: 1) word bepaal deur die aard van hulle opdrag naamlik om die hermeneutiese vooronderstellings van die Skrifgebruik by vrae rondom homoseksualiteit te bespreek. Ten spyte van hierdie beperking wat dié opdrag meebring in die beoordeling van homoseksualiteit word in die resultaat van die studie nie gewys op die belangrikheid dat die dogmatiese verstaan van die mens en sy seksualiteit, soos Brunner, Barth en Thielicke dit na vore gebring het, ook in berekening gebring moet word nie. Die skeppingsordeninge word as kragteloos geag omdat vele skeppingsordeninge(?) vandag afgeskaf is soos die doodstraf (Gen 9: 6), die verbod om bloed te eet (Gen 9:4) en die feit dat Paulus 'n grond vir egskeiding noem (1 Kor 7: 15). Die gevolgtrekking wat gemaak word is dat die ordeninge uitsonderings ken en dat die kerk die ordeninge nie onvoorwaardelik as moraal aanvaar nie maar telkens vra na die sin en die bedoeling daarvan (GKN 1981: 26). Alhoewel hiermee in 'n mate saamgestem kan word is die bedoeling om aan te dui dat dié toepassing van die evangelie nie reëlgebonde is nie (GKN 1981: 31) maar inhoudelik bepaal word deur die nood van die naaste. Die naaste moet gehelp word soos hulle gehelp wil word (GKN 1981: 47). Daarom spoor die deputate die gemeentes aan om ten opsigte van die homo- 
seksueel in die gemeente mekaar te aanvaar in 'n voortgaande proses van begrip en besinning (GKN 1981: 51). Die inhoud van die liefde wat as die hart van die Christelike etiek beskryf word (GKN 1981: 27), word deur die gemeente self verskaf (1981: 29). Op grond van 1 Korintiërs 9: 20 en Galasiërs 5: 6 word gestel dat dit gaan om die geloof wat deur liefde tot dade oorgaan (GKN 1981: 34). Die resultaat van hierdie siening is dat liefde aan die homoseksueel as naaste betoon behoort te word en dat hy gehelp moet word soos die homoseksueel self gehelp wil word. Dit impliseer dat homoseksualiteit in die sfeer van trou en vertroue nie veroordeel word nie (GKN 1981: 51). Dié denkmodel van die deputate word begrens deur die etiek van die dialoog wat Ott (1981: 188-189) voorstel. Die teologiese onderbou hiervoor is dat die syn van die mens 'n syn voor God is. Dit vorm die diepste grond vir die kommunikasie tussen mense. Vanuit die indikatief van die syn voor God word die imperatief vir die dialoog afgelei wat die gebod en norm vir die mens se lewe stel. Thielicke word onregmatig gesien as 'n eksponent van nuwere denke oor homoseksualiteit. Alhoewel Thielicke voorsiening maak vir die toelating van 'n vaste homoseksuele verhouding stel hy dit in die lig van die noagitiese verbond. Dit beteken dus ' $n$ toelating van ' $n$ verkeerdheid ter wille van die goeie orde en nie die relativering van liefde tot ' $n$ inhoudlose liefde nie.

Die verhouding tussen dogmatiek en etiek kan beskryf word in die woorde van Rothuizen (1973: 81). Hy beskryf dogmatiek as die beklemtoning van die regtheid van die geloof en etiek die beklemtoning van die egtheid van die geloof. Die eenheid tussen dogmatiek en etiek moet beklemtoon word sonder om daarmee te sê dat etiek bloot die uitvloeisel van dogmatiek is. Die etiek bevraagteken die opregtheid van die geloofshandeling van die mens binne 'n gegewe situasie. Om dit op 'n verantwoordelike wyse te doen en nie te verval in skolastiek of moralisme nie is nodig dat die dogmatiese aspekte in aanmerking geneem word saam met die ontleding van die situasie of fenomeen waarvoor etiese norme en ander dissiplines benodig word. Só gesien het etiek sy eie werksveld wat nie losgemaak mag word van sy dogmatiese bindinge nie. Hierdie beskouing van die verhouding tussen dogmatiek en etiek beteken dat vir die beoordeling van homoseksualiteit nie volstaan kan word met die gebod van God die Skepper, Versoener en Verlosser, die beskouing oor die huwelik en die beskouing oor die mens as man en vrou nie. Ander aspekte wat in aanmerking geneem sal moet word vir ' $n$ teologies beoordeling is die verhouding tussen wet en evangelie, gebod en gebooie, die navolging van Christus, 
naasteliefde en die eksegetiese ondersoek van Skrifgegewens oor homoseksualiteit. Hierby sal ook gegewens oor die fenomeen self versamel moet word ten einde te vra wie en wat die homoseksueel is. Eers aan die hand van al hierdie gegewens kan 'n verantwoordelike beoordeling gemaak word.

\section{Literatuurverwysings}

BARTH, K 1959. Kirchliche Dogmatik, Vol III/2. Zürich: EVZ-Verlag. BARTH, K 1960. Kirchliche Dogmatik, Vol I/2. Zürich: EVZ-Verlag.

BARTH, K 1964a. Kirchliche Dogmatik, Vol I/1. Zürich: EVZ-Verlag.

BARTH, K 1964b. Credo. London: Hodder and Stoughton.

BARTH, K 1969. Kirchliche Dogmatik, Vol III/4 Zürich: EVZ-Verlag.

BARTH, K 1970. Kirchliche Dogmatik, Vol III/1. Zürich: EVZ-Verlag.

BERKOUWER, GC 1974. Een halve eeuw theologie. Kampen: Kok.

BRUNNER, E 1934. Unsere Glaube. Zürich: Zwingli.

BRUNNER, E 1939. Das Gebot und die Ordnungen. Zürich: Swingli.

BRUNNER, E 1950. Die Christliche Lehre von Schöpfung und Erlösung. Zürich: Zwingli.

GEREFORMEERDE KERKEN NEDERLAND. Algemene Sinode 1981. Rapport over gebruik van Schriftgegewens bij vragen rondom Homofilie van deputaten Kerk en Theologie.

HENRY, FH 1973. Baker's Dictionary of Christian Ethics. Grand Rapids: Baker Book House. KRECK, W 1975. Grundfragen Christlicher Ethik. München: Kaiser.

LAU, F 1961. SV Schöpfungsordnung. RGG.

OTT, H 1981. Die Antwort des Glaubens: Systematische Theologie in 50 Artikeln. 3. erweiterte Aufl. Berlin: Kreuz.

RINGELING, H 1987. Homosexualität: Zum Ansatz der Problemstellung in der Theologische Ethik. Zeitschrift für Evangelische Ethik. Gutersloh: Mohn.

ROTHUIZEN, GTh 1973: Wat is ethiek? Kampen: Kok.

STECK, KG 1962. Natuur en genade in die Protestantse teologie. Brandpunte van de hedendaagse theologie. Hilversum: Paul Brand N.V.

THIELICKE, H 1968. Theologische Ethik, Vol III. Tübingen: Mohr.

THIELICKE, H 1981. Theologische Ethik, Vol I. Tübingen: Mohr.

WEBER, O 1967. Karl Barths Kirchliche Dogmatik. Ein einführende Bericht. Neukirchen Vluyn: Neukirchener Verlag. 